\title{
BELAJAR MEMAHAMI BAHASA GENERASI MILENIAL
}

\author{
Umar Mansyur \\ umar.mansyur@umi.ac.id
}

Istilah Generasi Milenial dewasa ini sedang viral, khususnya di media sosial. Netizen (warganet) sering menyebutnya dengan kids jaman now. Generasi ini hadir sebagai bentuk diferensiasi antara generasi zaman dulu yang eksis di tahun 90-an dengan generasi yang sedang eksis zaman sekarang. Dari segi usia, bisa dikatakan generasi milenial adalah mereka yang saat ini berada pada rentang umur 15-30 tahun.

Dalam Kamus Besar Bahasa Indonesia (KBBI) Edisi V, belum ditemukan terminologi milenial. Namun, tidak menutup kemungkinan Badan Bahasa Kemendikbud bisa menimbang hal tersebut agar diserap ke dalam KBBI versi daring (online) maupun luring (offline), serupa kata 'meme', 'viral', dan 'hoaks' yang telah lebih dulu menjadi kosakata baru bahasa Indonesia.

Istilah milenial atau millennials mulai dicetuskan oleh William Strauss dan Neil Howe pada tahun 1987. Mereka menciptakan istilah ini pada saat anak-anak yang lahir di tahun 1982 masuk prasekolah, dan media pada saat itu mulai menyebutnya sebagai kelompok yang terhubung ke milenium baru di saat lulus SMA tahun 2000. Keduanya menulis tentang kelompok ini dalam buku Generations: The History of America's Future Generations dan Millennials Rising: The Next Great Generation.

\section{Bahasa Indonesia dan Media Sosial}

Tidak dapat dimungkiri, perkembangan media sosial dewasa ini turut berpengaruh terhadap perkembangan bahasa Indonesia. Bahasa Indonesia yang berkedudukan sebagai bahasa nasional digunakan sebagai alat pengembangan kebudayaan nasional, ilmu pengetahuan dan teknologi. Kebudayaan nasional yang beragam, rasanya sulit disebarluaskan kepada seluruh masyarakat yang juga beragam bahasa daerah dengan menggunakan bahasa selain bahasa Indonesia. Hal 
ini juga berlaku dalam penyebarluasan ilmu pengetahuan dan teknologi modern, termasuk dalam penggunaan media sosial.

Media sosial dalam praktiknya menggunakan bahasa sebagai medium utama untuk saling berinteraksi. Bahasa menjadi prasyarat mutlak agar komunikasi para penggunanya dapat berjalan lancar. Di Indonesia, media sosial seperti facebook, instagram, dan twitter, menjadi media paling populer digunakan semua lapisan masyarakat untuk berkomunikasi atau sekadar unjuk diri. Merujuk pada hasil survei Asosiasi Penyelenggara Jasa Internet Indonesia (APJII) tahun 2016, pengguna internet di Indonesia telah mencapai 132,7 juta orang, dan facebook menjadi konten media sosial yang paling sering dikunjungi, yakni sebesar 54\%, disusul instagram, youtube, dan twitter.

Umumnya media sosial mayoritas diakses oleh kalangan remaja. Secara psikologi, pada usia remaja menjadi fase pertumbuhan manusia yang cenderung labil dan rentan terhadap berbagai macam pengaruh. Pengaruh media sosial bagi kalangan remaja dapat berwujud dalam gaya berpakaian (fashion) dan juga gaya berbahasa. Tak heran jika para remaja di zaman sekarang, ataukah yang dikatakan sebagai generasi milenial itu kerap menyebarkan istilah-istilah yang juga "labil" dari segi bahasa, yang kemudian telanjur viral di media sosial.

\section{Dari Tercyduk sampai Doyan Micin}

Penggunaan bahasa Indonesia dalam kehidupan sehari-hari harus memperhatikan konteks atau yang disebut dengan ragam bahasa. Ragam bahasa merupakan variasi bahasa menurut pemakaiannya, topik yang dibicarakan, hubungan pembicara dengan teman bicara, serta situasi pembicaraan. Ada ragam tulis dan lisan, ragam formal dan santai, ragam bahasa sosial, serta beragam konteks penggunaan bahasa Indonesia lainnya. Meskipun ragam bahasa Indonesia beraneka macam, tetapi masih tetap disebut bahasa Indonesia, sehingga dapat dipahami jika ada orang yang berbahasa Indonesia namun ditemukan beberapa perbedaan dalam perwujudan bahasa Indonesianya.

Bahasa atau istilah-istilah yang dipopulerkan para generasi milenial belakangan ini bisa dikatakan sebagai produk dari ragam bahasa sosial tertentu yang bersifat nonbaku. Maka, sepatutnya tidaklah salah jika banyak pengguna 
bahasa Indonesia di media sosial cenderung memakai bahasa Indonesia yang kurang sesuai dengan standar baku bahasa Indonesia. Namun, menurut Alwi dkk. (2003), ragam sosial sering dihubungkan dengan tinggi atau rendahnya status kemasyarakatan lingkungan sosial seseorang. Artinya, ragam baku bahasa Indonesia dapat berfungsi sebagai ragam sosial yang tinggi, sedangkan ragam baku daerah atau ragam sosial yang lain merupakan ragam sosial dengan nilai kemasyarakatan yang agak rendah. Selain itu, apa salah jika media sosial dijadikan sebagai sarana sosialisasi penggunaan kosakata bahasa Indonesia yang benar?

Jadi, sebelum beberapa istilah di media sosial telanjur viral atau diviralkan, maka alangkah baiknya jika penulisannya dilakukan secara benar. Mulai dari istilah 'tercyduk' yang seharusnya ditulis 'terciduk', doyan makan 'micin' ditulis menjadi doyan/suka makan 'vetsin', kids 'jaman' now ditulis menjadi kids 'zaman' now, dan lain sebagainya.

Oleh karena itu, para generasi milenial atau entah apapun namanya, secara sebagai orang Indonesia hendaknya selalu merasa bangga menggunakan bahasa Indonesia secara baik dan benar, karena bahasa Indonesia merupakan lambang identitas dan kebanggan nasional. (*) 